\title{
Description of odontogenic infection cases at the Oral Surgery Polyclinic of Hasan Sadikin Hospital Bandung, Indonesia
}

\author{
Ravitha Savitri*, Tis Karasutisna*, Agus Nurwiadh* \\ *Department of Oral Maxillofacial Surgery Faculty of Dentistry Universitas Padjadjaran, Indonesia
}

\section{ABSTRACT}

One of the most difficult cases to be managed in dentistry is an odontogenic infection. The study was aimed to finding the description of the odontogenic infection cases at the Oral Surgery Polyclinic of Hasan Sadikin Hospital, Bandung, Indonesia, according to the odontogenic infection types, genders, ages, sources of infection, and type of treatment given. This study was a retrospective-descriptive study with a survey method conducted from January 2009 to December 2010. The results of this study showed that there were total 8 types of odontogenic infection cases. The periapical abscess was the most frequent abscess found in 89 patients $(30.6 \%)$. Male patients were having more often cases than women with the ratio of 53:47. The most frequent age group was the $21-30$ years old age group in 57 patients (22.7\%). The highest number of patients from 8 different cases of odontogenic infection (30.2\%). The source of odontogenic infection was found most commonly by the mandibular first molar teeth, with as much as $26.6 \%$.

Keywords: Odontogenic infection cases, Oral Surgery Polyclinic, Hasan Sadikin Hospital

\section{INTRODUCTION}

Dental and oral disease placed the 6th highest disease of Indonesians according to the Indonesian National Household Health Survey in 2001 and ranked as the 4th most expensive illness in treatment according to The World Oral Health Report of 2003. ${ }^{1}$ According to the Health Profile of West Java Province in 2007, the oral health status of the West Java people was still not good, marked by increasing cases of dental and oral diseases from year to year. This condition was the result of the lack of knowledge and public awareness on the importance of oral health. ${ }^{2}$

Infection is the entry and development initiation of microorganisms into the body that causes inflammation. ${ }^{3}$ According to Mifflin in 2007, infection was a process of invasion and development of microorganisms on the body tissues that caused tissue injury, which subsequently developed into diseases through various cellular mechanisms or toxins. ${ }^{4}$ One of the infections difficult to be managed in dentistry is an odontogenic infection. This infection starts from a mild stage, such as a well-localized infection requiring only minimal treatment, then developed to the severe stages where the infection will spread to the spatium and may lead to death. ${ }^{5}$

Bacteria that causes odontogenic infections are usually part of the commensal flora of the oral cavity. When bacteria gain access to deeper tissues, such as pulpal necrosis or periodontal pocket, they will cause odontogenic infections. In the state of sufficient pathogenic bacteria and 
a weak body condition, periapical infections may spread to various spaces in the oral cavity. ${ }^{6}$

The good knowledge of infectious microorganisms and the spread of infection was required for the right medical diagnosis and determining the appropriate treatment. The study was aimed to finding the description of the odontogenic infection cases at the Oral Surgery Polyclinic of Hasan Sadikin Hospital, Bandung, Indonesia, according to the odontogenic infection types, genders, ages, sources of infection, and type of treatment given.

\section{METHODS}

This study was a retrospective-descriptive study with a survey method conducted at the Oral Surgery Polyclinic of Hasan Sadikin Hospital, Bandung, Indonesia, from January 2009 to December 2010. Materials used in this study was the odontogenic infected outpatient and inpatient's medical record card. The medical record card was obtained from the Medical Subsection of Hasan Sadikin Hospital.

The variables observed were as follows: odontogenic infection cases type; patient's genders and ages; sources of infection; and treatments given. The operational definitions of variables used were as follows: odontogenic infection cases types were various kind of odontogenic infections found in the patient's medical records such as abscess or phlegmon; and the source of infection was the tooth which caused the odontogenic infection.

The application of the research permission was performed prior to the survey. The survey was performed to the Medical Record Section of the Oral Surgery Polyclinic from January 2009 to December 2010. Data obtained were grouped based on the odontogenic infection cases type, gender and age of the patient, sources of infection and the type of treatments provided to the patient, Data were collected from outpatient and inpatient's medical records, then processed simply by using tables and diagrams with calculations and percentages.

\section{RESULTS}

From the survey performed to the Medical Record Section of the Oral Surgery Polyclinic from January 2009 to December 2010 found the results that the type of oral surgery cases found during the 2-years period was as many as 8 type of cases in 2159 people.

Table 1 showed that from these 2159 patients, found 51 cases of malignant tumor (2.36\%), 141 cases of benign tumor $(6.53 \%), 652$ infection cases (30.2\%), 225 hard tissue and soft tissue disorder (10.42\%), 369 congenital abnormalities (17.09\%), 139 salivary gland abnormalities $(6.44 \%), 35$ temporomandibular joint disorder cases (1.62\%), and 547 impaction cases (25.34\%).

From the results of this study also found 16 odontogenic infection cases type based on the anatomical location. Cases type found were the periapical abscess in 89 patients (30.6\%), submucous abscess in 4 patients $(1.4 \%)$, gingival abscess in 4 patients $(1.4 \%)$, buccal abscess in 42 patients $(14.4 \%)$, subcutaneous abscess in 10 patients $(3.4 \%)$, submandibular abscess in 87 patients $(29.9 \%)$, submental abscess in 29 patients $(10 \%)$, sublingual abscess in 4 patients

Table 1. Distribution of patients by oral surgery cases type

\begin{tabular}{|c|c|c|c|c|}
\hline Case type & 2009 & 2010 & Amount (patients) & Percentage (\%) \\
\hline Malignant tumor & 37 & 14 & 51 & 2.36 \\
\hline Benign tumor & 95 & 46 & 141 & 6.53 \\
\hline Infection & 414 & 238 & 652 & 30.20 \\
\hline Hard and soft tissue disorders & 148 & 77 & 225 & 10.42 \\
\hline Congenital abnormalities & 311 & 58 & 369 & 17.09 \\
\hline Salivary gland abnormalities & 88 & 51 & 139 & 6.44 \\
\hline Temporomandibular joint disorder & 11 & 24 & 35 & 1.62 \\
\hline Impaction & 411 & 136 & 547 & 25.34 \\
\hline Total & 1515 & 644 & 2159 & 100 \\
\hline
\end{tabular}


Table 2. Distribution of odontogenic infection patients by the infection type

\begin{tabular}{lcccc}
\hline Odontogenic infection cases type & 2009 & $\mathbf{2 0 1 0}$ & Amount (patients) & Percentage (\%) \\
\hline Periapical abscess & 43 & 46 & 89 & 30.6 \\
Submucous abscess & 2 & 2 & 4 & 1.4 \\
Gingival abscess & 0 & 4 & 4 & 1.4 \\
Buccal abscess & 21 & 21 & 42 & 14.4 \\
Subcutaneous abscess & 6 & 4 & 10 & 3.4 \\
Submandibular abscess & 37 & 50 & 87 & 29.9 \\
Submental abscess & 17 & 12 & 29 & 10 \\
Sublingual abscess & 2 & 2 & 4 & 1.4 \\
Submasseter abscess & 1 & 0 & 1 & 0.3 \\
Subparotic abscess & 1 & 0 & 1 & 0.3 \\
Palatal abscess & 1 & 2 & 3 & 1 \\
Retropharyngeal abscess & 3 & 1 & 4 & 1.4 \\
Parapharyngeal abscess & 1 & 0 & 1 & 0.3 \\
Temporal abscess & 2 & 0 & 2 & 0.7 \\
Peritonsillar abscess & 1 & 2 & 3 & 1 \\
Phlegmon & 6 & 1 & 7 & 2.4 \\
\hline \multicolumn{1}{c}{ Total } & 144 & 147 & 291 & 100 \\
\hline
\end{tabular}

Patients amount by gender female male

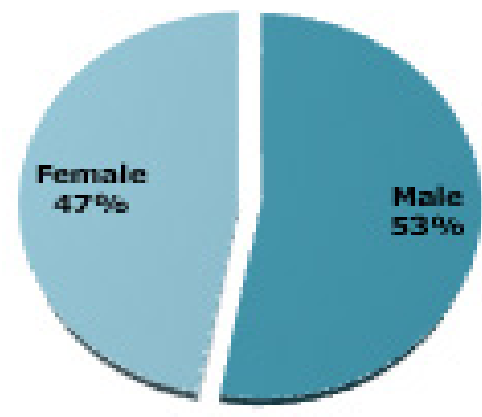

Figure 1. Percentage of odontogenic infection patients by gender

(1.4\%), submasseter and subparotic abscesses in respectively 1 patient $(0.3 \%)$, palatal abscess in 3 patients (1\%), retropharyngeal abscess in 4 patients $(1.4 \%)$, parafaringeal abscess in 1 patient $(0.3 \%)$, temporal abscess in 2 patients $(0.7 \%)$, and peritonsilar abscess in 3 patients (1\%), and phlegmon abscess in 7 patients (2.4\%) (Table 2).

Figure 1 was presenting the amount of odontogenic infections (251 patients) consisted of 133 male (53\%) and 118 female (47\%) patients. Figure 2 was presenting the distribution of odontogenic infection patients by age group ranged from 1-80 years old. Sequentially, the odontogenic infection patients most frequent age
Odontogenic infection patients amount by age group

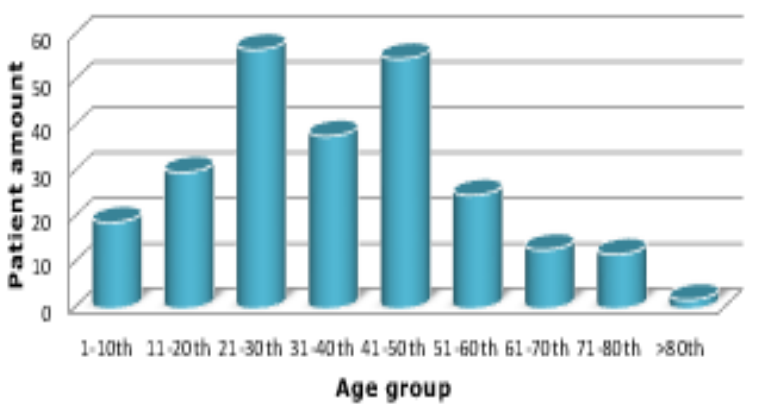

Figure 2. Odontogenic infection patientsamount by age group

group was the 21-30 years old age group, which was found in 57 patients $(22.7 \%$ ), followed by the 41-50 years old age group with as much as 55 patients $(21.9 \%)$, the $31-40$ years old age group in 38 patients (15.1\%), the $11-20$ years old age group in 30 patients $(12 \%)$, the $51-60$ years old age group in 25 patients (10\%), the $1-10$ years old age group in 19 patients (7.6\%), the $61-70$ years old age group in 13 patients $(5.2 \%)$, the $71-80$ years old age group in 12 patients (4.8\%), and the least frequent age group was above 80 years old age group, which was found in 2 patients $(0.8 \%)$. Table 3 showed that odontogenic infections were mostly initiated from mandibular teeth, which 
Table 3. Odontogenic infection patients by the infection source

\begin{tabular}{cccccccc}
\hline \multirow{2}{*}{ Tooth type } & \multirow{2}{*}{ Primary infection } & \multicolumn{2}{c}{ Maxilla } & \multicolumn{3}{c}{ Mandible } & \multicolumn{2}{c}{ Unknown } \\
\cline { 2 - 7 } & & $\mathrm{F}$ & $\%$ & $\mathrm{~F}$ & $\%$ & $\mathrm{~F}$ & $\%$ \\
\hline \multirow{5}{*}{ Permanent } & $\mathrm{I} 1$ & 1 & 0.4 & 1 & 0.4 & & \\
& $\mathrm{I}$ & 3 & 1.1 & 2 & 0.7 & & \\
& $\mathrm{C}$ & 3 & 1.1 & 1 & 0.4 & & \\
& $\mathrm{P} 1$ & 8 & 2.8 & 4 & 1.4 & & \\
& $\mathrm{P} 2$ & 5 & 1.8 & 6 & 2.1 & & \\
& $\mathrm{M} 1$ & 7 & 2.5 & 76 & 26.6 & & \\
& $\mathrm{M} 2$ & 8 & 2.8 & 26 & 9.1 & & \\
& $\mathrm{M} 3$ & 4 & 1.4 & 45 & 15.8 & & \\
Deciduous & $\mathrm{i} 1$ & 0 & 0 & 1 & 0.4 & & \\
& $\mathrm{i} 2$ & 1 & 0,4 & 1 & 0,4 & & \\
& $\mathrm{C}$ & 0 & 0 & 0 & 0 & & \\
\hline Total & $\mathrm{m} 1$ & 2 & 0.7 & 1 & 0.4 & & \\
\hline
\end{tabular}

was found in 169 cases $(59.3 \%)$, compared with only 44 cases $(15.4 \%)$ was initiated from maxillary teeth. The initial infection was found more in the permanent teeth than deciduous teeth. The infection source of the total of 72 cases (25.3\%), however, was unknown.

\section{DISCUSSION}

This retrospective study evaluated the odontogenic infections inpatient and outpatient's medical records at the Oral Surgery Polyclinic of Hasan Sadikin Hospital, Bandung, Indonesia, from January 2009 to December 2010.

The results of the study presented in Table 1 showed that within 2 years there were 8 types of oral surgery cases which were malignant tumors, benign tumors, infections, hard and soft tissue disorders, congenital abnormalities, salivary gland abnormalities, temporomandibular joint disorders, and impaction. Infection ranked first with the highest number of patients, found in as much as 652 patients $(30.2 \%)$ overall. This result was in contrast with the research conducted by Rahayu in 2003 Hasan Sadikin Hospital Bandung, Indonesia, from January 2001 to December 2002, which discovered the percentage of infected patients was only $26.65 \%$ overall and ranked as the second most oral surgery cases after third molar impaction. ${ }^{5}$ The increasing number of patients with such infection was probably caused by many cases of the side-effect infection of the extraction of the third molar impaction teeth, and also the postoperative complications. According to Peterson in 2003, infection was one of the most common complications of surgery caused by flaps in soft tissue and bone removal. ${ }^{5}$

Table 2 showed that 16 types of odontogenic infections were periapical abscess, submucous abscess, gingival abscess, buccal abscess, subcutaneous abscess, submandibular abscess, submental abscess, sublingual abscess, submasseter abscess, subparotic abscess, palatal abscess, retropharyngeal abscess, parapharyngeal abscess, temporal abscess, peritonsillar abscess, and a phlegmon abscess. Based on data obtained in this research, the most common odontogenic infections were a periapical abscess, which was found in 89 patients (30.6\%). A study conducted by Wulandari in 2000 on the pattern of odontogenic infections at Sartika Asih Hospital, Bandung, Indonesia, also showed that periapical abscess was the most common abscess found in odontogenic infections. ${ }^{6}$

A periapical abscess is an abscess initiated odontogenic infection found in the floor of the mouth, hard tissue, or the fascial spaces of the head and neck. A good host immune system can prevent the development of periapical abscess into another abscess. According to Thoma in 1969, the cause of dental infections goes through three stages: the stage of the periapical abscess, the 
extent to the spatial stage and the complication stage. ${ }^{7}$ An early treatment of the periapical abscess will prevent the spatial extent.

The results of the research shown in Figure 1 showed that the number of male patients was more than women with the ratio of $53: 47$. This result may caused by the higher concern regarding oral health in women more than men. When there is a problem in oral hygiene, women are more likely performing immediate treatment to prevent the dental problems continuation thus preventing the odontogenic infections development. Indonesia Basic Health Research (RISKESDAS) in 2007 also showed that the prevalence of treated dental and oral problems was slightly higher in women than men.

Figure 2 showed that the age group most frequently affected by odontogenic infection was the 21-30 years old group, which found in as many as 57 people $(22.7 \%)$ and the rarest affected was the age group above 80 years old which only in 2 patients $(0.8 \%)$. In the 21-30-years old age group, found many odontogenic infections, probably due to a large number of male patients suffering from molar tooth decay due to massive caries. In the age group above 80 years old rarely found odontogenic infections because most people at this age usually have no teeth. According to the life rates, the age group of 21-30 years old is a productive age with a high life rate, while the age group of above 80 years old and has a fairly low life rate.

Table 3 presented that mandibular teeth more commonly became the odontogenic infection source which found in 169 cases (59.3\%) compared to 44 cases $(15.4 \%)$ found in maxillary teeth. This condition occurred because, in the process of mastication, food was retained on the mandibular teeth. Moreover, the food retention was the initiation of caries and will be developed into a further infection.

The most common source of the tooth infection was the lowest mandibular first molar tooth, which was found in 76 cases $(26.6 \%)$. This result was reinforced by Cawson's statement in 1991 stated that the main cause of abscesses in facial spasm was increased in the lower molar region. ${ }^{8}$ This condition was due to the mandibular first molar was the first permanent tooth eruption that bears the most mastication load. Therefore, the lower first mandibular molars are more rapidly damaged.
Odontogenic infection patients should be treated immediately to prevent the infection development thus causes complications that can threaten the patient's life. The treatment given to the patient depends on the patient's condition. Treatment with antibiotics, tooth extraction of the causative agent, and also incision and drainage are the most common treatments for odontogenic infections. The main principle of odontogenic infections handling is to perform surgery for drainage and removing the cause of infection. Administration of antibiotics was necessary to prevent widespread infection, controlling infection to ensure immediate tooth extraction, and handling of patients with low body resistance. ${ }^{9}$

Patients with a periapical abscess case are most likely treated with the tooth extraction and antibiotic administration. Based on the results of this research noted that most of the tooth of infection source was the non-vital teeth that can not be maintained due to the gangrene pulp and radicular. Extraction is one way to eliminate the source of infection. If the infectious tooth can still be maintained, endodontic treatment can be performed to eliminate the infection.

\section{CONCLUSION}

Odontogenic infections ranked the first from 8 types of oral surgery cases with the amount of patients were as much as $30.2 \%$ overall. The periapical abscess was the most common abscess with as much as $30.6 \%$ overall. Odontogenic infections were found more in male patients compared to female patients (53\%: 47\%). The age group frequently affected by odontogenic infection was the age group of 21 - 30 years, which was as much as $22.7 \%$ overall. The source of odontogenic infection most commonly was the mandibular first molars, which was found in as much as $26.6 \%$ overall.

\section{REFERENCES}

1. Silalahi JL. Kebutuhan dan perilaku akan perawatan penyakit periodontal pada masyarakat umur 15-65 tahun di Kecamatan Pangururan Kabupaten Samosir, Tahun 2010 [minor thesis]. Medan: USU; 2010.

2. Health Office of West Java Province. Profil 
Kesehatan Provinsi Jawa Barat Tahun 2007. Bandung: Ministry of Health of Republic of Indonesia; 2007.

3. Markam, S. Kamus Kedokteran. $5^{\text {th }}$ ed. Jakarta; Balai Penerbit Fakultas Kedokteran Universitas Indonesia; 2008.

4. American Heritage Dictionary. The American Heritage Medical Dictionary. Boston; Houghton Mifflin Company; 2007.

5. Peterson LJ. Contemporary Oral and Maxillofacial Surgery. $4^{\text {th }}$ ed. St. Louis: MosbyElsevier; 2005.

6. Wulandari. Pola Infeksi Odontogenik di Rumah
Sakit Sartika Asih Bandung Periode Januari 1995 - Desember 1999 [minor thesis]. Bandung: Unpad; 2000.

7. Thoma KH. Oral Surgery. 5th ed. St. Louis: Mosby-Elsevier; 1969.

8. Cawson RA. Essential of Dental Surgery and Pathology. $5^{\text {th }}$ ed. London: Churchill Livingstone; 1991.

9. Rahayu YS. Pola Kasus Bedah Mulut di Bagian Bedah Mulut Perjan Rumah Sakit Dr.Hasan Sadikin Bandung Periode Januari 2001-Desember 2002 [minor thesis]. Bandung: Unpad; 2003. 